\title{
Interaksi Plant Growth Promoting Rhizobacteria Dosis Pemupukan P dalam Memacu Pertumbuhan dan Mengendalikan Penyakit Antraknosa pada Cabai Merah
}

\section{Interaction of Plant Growth-Promoting Rhizobacteria (PGPR) and P Fertilizer onAnthracnose Disease, Growth and Yield of Chili Pepper}

\author{
Rizki Amalia', Memen Surahman², Suryo Wiyono ${ }^{1,3^{*}}$ \\ ${ }^{1}$ Departemen Proteksi Tanaman, Fakultas Pertanian, IPB, Jl. Meranti Kampus Darmaga, Bogor 16680, Indonesia \\ ${ }^{2}$ Departemen Agronomi dan Hortikultura, Fakultas Pertanian Institut Pertanian Bogor \\ Jl. Meranti Kampus IPB Darmaga, Bogor, Indonesia \\ ${ }^{3}$ Pusat Kajian Hortikultura Tropika (PKHT) Institut Pertanian Bogor, Kampus IPB Baranangsiang \\ Jl. Raya Pajajaran Bogor, Indonesia
}

Diterima 1 Januari 2019/Disetujui 22 Februari 2019

\begin{abstract}
The aims of this research were to investigate the effect of Plant Growth-Promoting Rhizobacteria (PGPR) and $P$ fertilizer on anthtracnose caused by Colletotrichum sp. Plant growth and yield of hot pepper under field condition. The research was arranged in split plot design with two factors. The first factor is aplication of PGPR which consists of two treatments that were without PGPR and with PGPR. The second factor is application of P fertilizer which consists of four treatment of SP 36 fertilizers that were $250 \mathrm{~kg}, 187.5 \mathrm{~kg}, 125 \mathrm{~kg}$, and $62.5 \mathrm{~kg}$. Application P fertilizer affect growth parameters of chili pepper but have no effect on antrachnose disease. PGPR was able to control antrachnose under field application, and promoted plant growth parameters and yield. PGPR application increase emergence rate and vigor index of treated seeds. There was interaction between PGPR and P fertilizer dose regarding with growth, with optimum field dose is $125 \mathrm{~kg}$ SP $36 \mathrm{ha}^{-1}$.
\end{abstract}

Keywords: biological control, Colletotrichum, seed production

\section{ABSTRAK}

Penelitian bertujuan untuk mengevaluasi pengaruh Plant Growth-Promoting Rhizobacteria (PGPR) dan pupuk $P$ terhadap penyakit on antraknosa yang disebabkan oleh Colletotrichum sp. Pertumbuhan tanaman dan daya hasil pada tanaman cabai dilakukan di kebun percobaan. Penelitian dilakukan menggunakan rancangan percobaan split plot dua faktor. Faktor pertama (petak utama) adalah perlakuan benih dengan dua taraf perlakuan yaitu tanpa pemberian PGPR (SO) dan pemberian PGPR (S1). Faktor kedua adalah dosis pemupukan P yang terdiri dari empat taraf yaitu : pemupukan $P$ dalam bentuk SP36 dengan dosis $250 \mathrm{~kg} \mathrm{ha}^{-1}$ (P1), $187.5 \mathrm{~kg} \mathrm{ha}^{-1}$ (P2), $125 \mathrm{~kg} \mathrm{ha}^{-1}$ (P3), $62.5 \mathrm{~kg} \mathrm{ha}^{-1}$ (P4). Aplikasi pupuk $P$ terhadap peubah pertumbuhan tanaman cabai tidak memberikan pengaruh terhadap penyakit antraknosa. PGPR mampu mengendalikan antraknosa pada kondisi lapang dan meningkatkan pertumbuhan serta daya hasil. Aplikasi PGPR meningkatkan daya tumbuh dan indeks vigor pada benih. PGPR dan dosis pupuk P menunjukan interaksi terhadap pertumbuhan dengan dosis optimal adalah $125 \mathrm{~kg} \mathrm{SP} 36 \mathrm{ha}^{-1}$.

Kata kunci: Colletotrichum, pengendalian biologi, produksi benih

\section{PENDAHULUAN}

Luas areal pertanaman cabai menempati urutan pertama terluas dibandingkan dengan tanaman sayuran lainnya yaitu mencapai 174,708 ha atau sekitar $14.27 \%$ dari total areal pertanaman sayuran (Deptan, 2005), namun secara nasional produktivitas cabai masih rendah yaitu 6 ton ha- ${ }^{-1}$ (BPS, 2005), sementara potensi produksinya dapat mencapai 20

\footnotetext{
* Penulis untuk korespondensi. e-mail: suryowi269@gmail.com
}

ton ha ${ }^{-1}$ (Duriat et al., 1999). Rendahnya produksi cabai disebabkan oleh faktor agronomis dan adanya gangguan hama dan penyakit tanaman (Semangun, 1996).

Unsur Posfor (P) berfungsi sebagai pemacu pertumbuhan dan pembentukan akar awal, membuat tanaman tegar serta merangsang pembungaan dan membantu pembentukan biji. Kurangnya $\mathrm{P}$ tersedia dalam tanah pada umumnya akan menghambat pertumbuhan tanaman. Defisiensi posfor diketahui banyak terjadi di seluruh wilayah Indonesia (Hasanudin, 2002). 
Penggunaan Plant Growth Promoting Rhizobacteria (PGPR) sebagai bakteri pelarut fosfat dapat dijadikan alternatif cara dalam usaha meningkatkan $\mathrm{P}$ tersedia bagi tanaman. Kemampuan PGPR untuk memproduksi IAA dan siderofor juga merupakan salah satu faktor yang mendukung pertumbuhan dan peningkatan hasil tanaman serta mampu menurunkan tingkat kejadian penyakit antraknosa yang merupakan salah satu penyakit penting tanaman cabai (Sutariati, 2006). Penelitian ini bertujuan untuk mempelajari pengaruh pemberian Rizobakteri Pemacu Pertumbuhan Tanaman (PGPR) dan pemupukan P dengan dosis yang berbeda di lapangan terhadap viabilitas benih, pertumbuhan dan produksi cabai merah (Capsicum annuum), serta ketahanan terhadap penyakit antraknosa.

\section{BAHAN DAN METODE}

\section{Bahan dan Alat}

Bahan yang digunakan dalam penelitian yaitu benih cabai merah (Capsicum annuum L) varietas Tit Super LV, Rizobakteri Pemacu Pertumbuhan Tanaman (PGPR) campuran isolat bakteri Pseudomonas fluorescens dan Bacillus polymixa yang telah diformulasikan (diperoleh dari Klinik Tanaman, Departemen Proteksi Tanaman, Fakultas Pertanian, IPB), kertas merang, kertas hisap, larutan hipoklorit $1 \%(\mathrm{NaOCl} 1 \%)$, alkohol, air steril, pupuk organik, tanah steril, pupuk NPK mutiara, pupuk kandang, pupuk Urea, pupuk SP-36, pupuk KCl, curacron, dan petrogenol. Alatalat yang digunakan yaitu alat pengecambah benih (APB) IPB73-2A/B, kertas merang, kertas saring, cawan petri, timbangan analitik, gelas ukur, laminar air flow cabinet, near ultra violet (NUV), mikroskop, hand sprayer, tray semai, jangka sorong, meteran, sarana produksi pertanian, alat tulis, perangkap hama dan mulsa plastik hitam perak.

\section{Metode Penelitian}

Rancangan percobaan yang digunakan adalah Rancangan Petak Terbagi (Split Plot Design) yang terdiri dari dua faktor. Faktor pertama (petak utama) adalah perlakuan benih dengan dua taraf perlakuan yaitu tanpa pemberian PGPR (S0) dan pemberian PGPR (S1). Faktor kedua adalah dosis pemupukan $\mathrm{P}$ yang terdiri dari empat taraf yaitu : pemupukan P dalam bentuk SP36 dengan dosis $250 \mathrm{~kg} \mathrm{ha}^{-1}$ (P1), $187.5 \mathrm{~kg} \mathrm{ha}^{-1}$ (P2), $125 \mathrm{~kg} \mathrm{ha}^{-1}$ (P3), 62.5 $\mathrm{kg} \mathrm{ha}^{-1}$ (P4). Setiap satuan percobaan terdiri dari 20 tanaman sehinga dalam penelitian ini terdapat 480 tanaman. Apabila dalam perlakuan pemupukan menunjukkan pengaruh yang nyata terhadap hasil pengamatan, maka akan dilakukan analisis uji lanjut dengan metode Duncan Multiple Range Test (DMRT) pada taraf 5\%.

\section{Pelaksanaa Seed treatment, Persemaian dan Transplanting}

Perlakuan benih dilakukan sebelum pembibitan dengan merendam benih dalam suspensi PGPR $\left(10^{7} \mathrm{cfu}\right.$ $\mathrm{mL}^{-1}$ ) selama 12 jam. Selanjutnya benih disemaikan dalam tray dengan media berupa campuran pupuk organik dan tanah steril (1:3). Pemindahan bibit ke lapang dilakukan setelah bibit berumur 30 hari setelah semai (HSS) pada lubang tanam yang telah disiapkan dengan jarak tanam 50 $\mathrm{cm} \times 50 \mathrm{~cm}$.

\section{Pemupukan}

Pupuk $\mathrm{KCl}$ dengan dosis $200 \mathrm{~kg} \mathrm{ha} \mathrm{ha}^{-1}$ diberikan dalam dua tahap yaitu pada saat tanam dan satu bulan setelah tanam (BST). Pupuk urea dengan dosis $250 \mathrm{~kg} \mathrm{ha}^{-1}$ diberikan dalam tiga tahap yaitu pada saat tanam, dua BST, dan tiga BST. Sedangkan pupuk P yang terdiri dari empat taraf dengan dosis masing-masing $250 \mathrm{~kg} \mathrm{ha}^{-1}(100 \%)$, $187.5 \mathrm{~kg} \mathrm{ha}^{-1}(75 \%), 125 \mathrm{~kg} \mathrm{ha}^{-1}(50 \%)$, dan $62.5 \mathrm{~kg} \mathrm{ha}^{-1}$ (25\%) diberikan pada saat tanam. Perlakuan PGPR susulan dilakukan dengan menyiramkan suspensi PGPR sebanyak $50 \mathrm{ml}$ per tanaman $\left(10^{6} \mathrm{cfu} \mathrm{ml}^{-1}\right)$ dengan menggunakan jenis bakteri yang sama seperti pada perlakuan benih awal.

\section{Pemeliharaan dan Pemanenan}

Pengendalian hama dilakukan dengan menggunakan curacron untuk mengendalikan kutu daun dan petrogenol untuk mengendalikan lalat buah. Pemanenan dilakukan setelah tanaman menghasilkan buah layak panen dengan frekuensi 2 kali seminggu. Panen pertama pada 10 MST dan panen terakhir pada 13 MST.

\section{Uji Viabilitas Benih}

Uji viabilitas benih dilakukan dengan menggunakan metode Uji Di atas Kertas (UDK). Kertas merang yang telah dilembabkan diletakkan di dalam cawan petri. Tiap cawan petri berisi 50 benih dan diulang sebanyak tiga kali. Selanjutnya cawan petri diinkubasi dalam alat pengecambah benih (APB) IPB 73-2A/B.

Pengujian viabilitas benih awal dilakukan terhadap benih yang mengalami proses seed treatment dengan menggunakan suspensi PGPR secara langsung. Sedangkan pengujian viabilitas benih akhir dilakukan dengan menggunakan benih hasil pertanaman yang telah mendapatkan kombinasi perlakuan PGPR dan pemupukan P selama di lapang.

\section{Pengamatan}

Pengamatan variabel pertumbuhan tanaman, peubahpeubah yang diamati meliputi tinggi tanaman, diameter batang dan jumlah cabang, dilakukan setiap dua minggu hingga 10 minggu setelah tanam (MST). Pengamatan parameter produksi tanaman, peubah-peubah yang diamati meliputi, bobot buah per tanaman, jumlah buah per tanaman dan bobot buah layak pasar per tanaman. Penghitungan dilakukan terhadap buah yang layak dipasarkan dengan kriteria buah sehat, panjang minimal $5 \mathrm{~cm}$ dan bobot minimal $5 \mathrm{~g}$. 
Tingkat Kejadian Penyakit Antraknosa, dihitung dengan rumus :

$$
\text { 1. } K P \text { tanaman }=\frac{n}{N} \times 100 \%
$$

Keterangan $:$ KP tanaman $=$ kejadian penyakit pada tanaman $(\%), \mathrm{n}=$ jumlah tanaman positif terserang, $\mathrm{N}=$ jumlah tanaman yang diamati.

2. $\quad K P$ buah $=\frac{n}{N} \times 100 \%$

Keterangan : KP buah $=$ Kejadian Penyakit pada buah (\%), $\mathrm{n}=$ jumlah buah positif terserang, $\mathrm{N}=$ jumlah buah yang diamati

Pengamatan parameter viabilitas benih dan mutu patologis benih, peubah-peubah yang diamati meliputi:

1. Daya berkecambah (DB), dihitung berdasarkan persentase kecambah normal (KN) hitungan pertama yaitu 7 hari setelah tanam (HST) dan kedua 14 hst dengan rumus:

$$
D B=\frac{\sum \mathrm{K} N \text { hitungan } I+K N \text { hitungan } I I}{\sum \text { benih yang ditanam }} \times 100 \%
$$

2. Indeks vigor (IV)), dihitung berdasarkan persentase kecambah normal pada hitungan pertama ( $7 \mathrm{hst}$ ) dengan rumus:

$$
I V=\frac{\sum K N \text { hitungan } I}{\sum \text { benih yang ditanam }} \times 100 \%
$$

3. Kecepatan tumbuh $\left(\mathrm{K}_{\mathrm{CT}}\right)$ dihitung berdasarkan akumulasi kecepatan tumbuh harian (Sadjad et al. 1999) dengan rumus:

$$
K_{C T}=\sum_{0}^{t n} \frac{N}{t}
$$

Keterangan $: \mathrm{t}=$ waktu pengamatan, $\mathrm{N}=\% \mathrm{KN}$ setiap waktu pengamatan, $\mathrm{tn}=$ waktu akhir pengamatan

Cendawan terbawa benih, menggambarkan persentase jumlah benih yang membawa cendawan Colletotrichum capsici dari penelitian di lapang.

Cendawan terbawa benih $=$

$$
\frac{\sum \text { benih terserang cendawan Colletotrichum capsici }}{\sum \text { benih yang ditanam }} \times 100 \%
$$

\section{HASIL DAN PEMBAHASAN}

Persemaian dilakukan di dekat lokasi penanaman dengan menggunakan naungan berupa plastik bening yang mampu melindungi dari terpaan angin dan hujan namun tidak menghalangi jalannya sinar matahari. Pemindahan bibit ke lapang dilakukan ketika tanaman berumur 4 MSS, dengan tinggi tanaman 10-15 cm. Suhu di lapangan berkisar antara $21.8-31.6{ }^{\circ} \mathrm{C}$. Curah hujan selama masa penelitian berkisar antara 196 - $572 \mathrm{~mm}$ bulan $^{-1}$. Hasil analisis tanah menunjukkan bahwa lahan untuk lokasi penanaman mempunyai $\mathrm{P}$ tersedia 39 ppm dan $\mathrm{pH}$ 5.4, sehingga tergolong tanah masam dengan $\mathrm{P}$ tersedia tergolong agak rendah, sedangkan tekstur tanah terdiri dari 55\% liat, 33\% debu dan $12 \%$ pasir.

Selama penelitian pertanaman cabai secara alami mendapatkan infeksi penyakit antraknosa (Colletotrichum sp.) yang menyerang batang dan buah cabai. Serangan penyakit ini terjadi sejak tanaman berumur 1 MST sampai akhir pengamatan. Sebagian besar penyakit menyerang batang utama (dicotomus), sehingga sangat sulit jika harus memangkas bagian yang terserang penyakit saja. Hama tanaman tidak menunjukkan serangan yang berarti selama proses penelitian, namun tetap dilakukan upaya pencegahan dengan menggunakan petrogenol dan curacron 500 EC 2.5 $\mathrm{ml} \mathrm{L}^{-1}$.

\section{Pertumbuhan}

\section{Tinggi Tanaman}

Berbagai taraf pemupukan P menghasilkan perbedaan yang nyata terhadap tinggi tanaman pada 2, 4, dan 6 MST. Tabel 1 menunjukkan bahwa taraf pemupukan P $125 \mathrm{~kg} \mathrm{SP}-$ $36 \mathrm{ha}^{-1}$ menunjukkan nilai rata-rata tinggi tanaman yang lebih baik pada 2 MST. Sedangkan pemupukan P dengan dosis $250 \mathrm{~kg} \mathrm{SP-36} \mathrm{ha}^{-1}$ menunjukkan hasil terbaik pada 4 MST dan 6 MST.

Perlakuan PGPR tidak berpengaruh nyata terhadap tinggi tanaman, walaupun eecara keseluruhan, tanaman yang diberi perlakuan PGPR memiliki tinggi tanaman lebih besar daripada tanpa PGPR. Interaksi pemberian PGPR dan pemupukan $P$ nyata terhadap tinggi tanaman pada 2 MST. Tabel 2 menunjukkan bahwa tanaman yang mendapat perlakuan PGPR dan diberi pupuk dengan dosis $125 \mathrm{~kg}$ SP-36 ha-1 memiliki tinggi tanaman paling besar dibanding kombinasi perlakuan lainnya. Namun pada umur selanjutnya tidak terlihat perbedaan tinggi tanaman akibat interaksi kedua perlakuan.

\section{Diameter Batang}

Pemupukan P pada berbagai taraf berpengaruh nyata terhadap diameter batang pada umur 2 MST. Nilai tertinggi ditunjukkan oleh pemberian pupuk P dosis $125 \mathrm{~kg}$ SP-36 $\mathrm{ha}^{-1}$ mencapai $2.98 \mathrm{~mm}$ (Tabel 3). Hasil analisis sidik ragam menunjukkan bahwa pengaruh interaksi antara pemberian PGPR dan pemupukan P berpengaruh sangat nyata terhadap diameter batang ketika tanaman berumur 2 MST. Tabel 4 menunjukkan bahwa tanaman tanpa PGPR dan diberi pupuk P dosis $125 \mathrm{~kg} \mathrm{SP}-36$ ha $^{-1}$ memiliki diameter batang paling besar. Meskipun demikian, tidak terdapat perbedaan diameter batang pada pengamatan selanjutnya akibat interaksi kedua perlakuan. Perlakuan dengan pemberian PGPR dengan dosis pupuk P $125 \mathrm{~kg} \mathrm{ha}^{-1}$ menunjukan diameter terbesar, dan tidak berbeda nyata dengan dosis pupuk $7.5 \mathrm{~kg} \mathrm{ha}^{-1}$. 
Tabel 1. Rekapitulasi hasil analisis sidik ragam pengaruh pemberian PGPR dan pemupukan P pada berbagai peubah pengamatan

\begin{tabular}{|c|c|c|c|c|c|}
\hline & \multirow{2}{*}{ Peubah Pengamatan } & \multirow{2}{*}{ Umur (MST) } & \multicolumn{3}{|c|}{ Perlakuan } \\
\hline & & & PGPR & $P$ & PGPRxP \\
\hline \multirow[t]{15}{*}{ Pertumbuhan } & Tinggi tanaman & 2 & tn & $*$ & $*$ \\
\hline & & 4 & tn & $*$ & tn \\
\hline & & 6 & tn & $*$ & tn \\
\hline & & 8 & tn & tn & $\operatorname{tn}$ \\
\hline & & 10 & $\operatorname{tn}$ & tn & $\operatorname{tn}$ \\
\hline & Diameter batang & 2 & $\operatorname{tn}$ & $*$ & $* *$ \\
\hline & & 4 & tn & tn & tn \\
\hline & & 6 & tn & tn & tn \\
\hline & & 8 & tn & tn & tn \\
\hline & & 10 & tn & tn & tn \\
\hline & Jumlah cabang & 2 & $\operatorname{tn}$ & tn & $\operatorname{tn}$ \\
\hline & & 4 & $\operatorname{tn}$ & tn & $\operatorname{tn}$ \\
\hline & & 6 & tn & tn & tn \\
\hline & & 8 & $\operatorname{tn}$ & tn & $\operatorname{tn}$ \\
\hline & & 10 & $* *$ & $*$ & $*$ \\
\hline \multirow[t]{3}{*}{ Produksi } & Bobot total per tanaman & & $\operatorname{tn}$ & tn & tn \\
\hline & Bobot layak pasar per tanaman & & tn & tn & tn \\
\hline & Jumlah buah per tanaman & & $\operatorname{tn}$ & tn & $\operatorname{tn}$ \\
\hline \multicolumn{6}{|l|}{ Kejadian penyakit } \\
\hline & Kejadian penyakit pada tanaman & 1 & $\operatorname{tn}$ & tn & tn \\
\hline & & 2 & tn & tn & tn \\
\hline & & 3 & tn & tn & tn \\
\hline & & 4 & tn & tn & tn \\
\hline & & 5 & tn & tn & tn \\
\hline & & 6 & tn & tn & tn \\
\hline & & 7 & tn & tn & tn \\
\hline & & 8 & tn & tn & tn \\
\hline & & 9 & $\operatorname{tn}$ & tn & $\operatorname{tn}$ \\
\hline & & 10 & th & tn & tn \\
\hline & & 11 & tn & tn & tn \\
\hline & & 12 & tn & tn & tn \\
\hline & Kejadian penyakit pada buah & & $*$ & tn & tn \\
\hline & Kejadian penyakit tanaman semusim & & tn & tn & tn \\
\hline \multirow[t]{3}{*}{ Viabilitas benih awal } & Daya berkecambah & & $* *$ & tn & tn \\
\hline & Indeks vigor & & $*$ & tn & tn \\
\hline & Kecepatan tumbuh & & tn & tn & $\operatorname{tn}$ \\
\hline \multirow[t]{3}{*}{ Viabilitas benih akhir } & Daya berkecambah & & tn & tn & tn \\
\hline & Indeks vigor & & $* *$ & tn & $\operatorname{tn}$ \\
\hline & Kecepatan tumbuh & & $\operatorname{tn}$ & tn & $\operatorname{tn}$ \\
\hline
\end{tabular}

Keterangan : $\quad$ PGPR $=$ perlakuan pemberian PGPR, $\mathrm{P}=$ perlakuan pemupukan $\mathrm{P}, \mathrm{PGPRxP}=$ kombinasi perlakuan pemberian $\mathrm{PGPR}$ dan pemupukan $\mathrm{P}, *=$ berbeda nyata pada taraf $5 \%, * *=$ berbeda sangat nyata pada taraf $1 \%$, tn = tidak berbeda nyata 


\section{Jumlah Cabang}

PGPR berpengaruh sangat nyata terhadap jumlah cabang pada $10 \mathrm{MST}$, dan pemupukan $\mathrm{P}$ berpengaruh nyata terhadap jumlah cabang pada umur yang sama, sedangkan pada pengamatan sebelumnya tidak terjadi perbedaan jumlah cabang akibat perlakuan-perlakuan yang diberikan. Tabel 5 menunjukkan bahwa pemberian PGPR dan pemupukan

Tabel 1. Tinggitanaman (cm) pada berbagai taraf pemberian PGPR dan pemupukan $\mathrm{P}$

\begin{tabular}{llllll}
\hline \multirow{2}{*}{ Perlakuan } & \multicolumn{5}{c}{ Umur tanaman } \\
\cline { 2 - 6 } & $2 \mathrm{mst}$ & $4 \mathrm{mst}$ & $6 \mathrm{mst}$ & $8 \mathrm{mst}$ & $10 \mathrm{mst}$ \\
\hline Pemberian PGPR & & & & \\
\hline Tanpa PGPR & 16.009 & 30.438 & 48.184 & 53.107 & 55.439 \\
PGPR & 17.872 & 32.546 & 49.313 & 54.888 & 56.504 \\
\hline Pemupukan P (SP-36 ha $\left.\mathrm{ha}^{-1}\right)$ & & & \\
\hline $250 \mathrm{~kg}$ & $16.500 \mathrm{~b} 33.030 \mathrm{a}$ & $50.862 \mathrm{a}$ & 55.962 & 51.44 \\
$187.5 \mathrm{~kg}$ & $16.815 \mathrm{~b} 31.880 \mathrm{a}$ & $50.133 \mathrm{a}$ & 54.928 & 57.003 \\
$125 \mathrm{~kg}$ & $17.808 \mathrm{a} 31.658 \mathrm{a}$ & $49.322 \mathrm{a}$ & 54.635 & 56.425 \\
$62.5 \mathrm{~kg}$ & $16.488 \mathrm{~b} 29.225 \mathrm{~b} 44.678 \mathrm{~b}$ & 50.463 & 53.018 \\
\hline
\end{tabular}

Keterangan : angka yang diikuti oleh huruf yang sama pada kolom dan baris yang berbeda menunjukkan tidak berbeda nyata menurut hasil uji DMRT pada taraf 5\%

Tabel 2. Tinggi tanaman $(\mathrm{cm})$ umur 2 MST pada interaksi berbagai taraf pemberian PGPR dan pemupukan $\mathrm{P}$

\begin{tabular}{lcc}
\hline \multirow{2}{*}{$\begin{array}{c}\text { Pemupukan P } \\
(\text { SP-36 ha-1) }\end{array}$} & \multicolumn{2}{c}{ Pemberian PGPR } \\
\cline { 2 - 3 } $250 \mathrm{~kg}$ & Tanpa PGPR & PGPR \\
$187.5 \mathrm{~kg}$ & $15.623 \mathrm{dc}$ & $17.677 \mathrm{ab}$ \\
$125 \mathrm{~kg}$ & $16.820 \mathrm{bc}$ & $16.810 \mathrm{bc}$ \\
$62.5 \mathrm{~kg}$ & $17.103 \mathrm{~b}$ & $18.513 \mathrm{a}$ \\
\hline
\end{tabular}

Keterangan : angka yang diikuti oleh huruf yang sama pada kolom dan baris yang berbeda menunjukkan tidak berbeda nyata menurut hasil uji DMRT pada taraf 5\%

Tabel 3. Diameter batang (mm) pada berbagai taraf pemberian PGPR dan pemupukan $\mathrm{P}$

\begin{tabular}{lrrrrr}
\hline \multirow{2}{*}{$\begin{array}{c}\text { Pemupukan P } \\
\left(\mathrm{SP}-36 \mathrm{ha}^{-1}\right)\end{array}$} & \multicolumn{5}{c}{ Umur tanaman } \\
\cline { 2 - 6 } & $2 \mathrm{mst}$ & $4 \mathrm{mst}$ & $6 \mathrm{mst}$ & $8 \mathrm{mst}$ & $10 \mathrm{mst}$ \\
\hline $250 \mathrm{~kg}$ & $2.745 \mathrm{~b}$ & 4.64 & 6.95 & 7.597 & 8.68 \\
$187.5 \mathrm{~kg}$ & $2.945 \mathrm{ab}$ & 4.647 & 6.878 & 7.565 & 8.683 \\
$125 \mathrm{~kg}$ & $2.983 \mathrm{a}$ & 4.655 & 6.705 & 7.57 & 8.55 \\
$62.5 \mathrm{~kg}$ & $2.737 \mathrm{~b}$ & 4.573 & 6.48 & 7.592 & 8.248 \\
\hline
\end{tabular}

P dengan dosis $250 \mathrm{~kg} \mathrm{SP}-36 \mathrm{ha}^{-1}$ menunjukkan nilai ratarata jumlah cabang yang lebih besar dibanding perlakuan lainnya. Interaksi antara pemberian PGPR dan pemupukan $\mathrm{P}$ nyata terhadap jumlah cabang ketika tanaman berumur 10 MST. Tabel 6 menunjukkan bahwa tanaman yang mendapat perlakuan PGPR dan diberi pupuk dengan dosis $250 \mathrm{~kg} \mathrm{ha}^{-1}$ memiliki jumlah cabang paling besar.

\section{Produksi}

Secara umum, tidak ada pengaruh nyata pemberian PGPR dan pemupukan P terhadap bobot buah per tanaman, bobot buah layak pasar per tanaman, dan jumlah buah per tanaman selama masa pengamatan, baik secara tunggal maupun interaksi kedua perlakuan.

\section{Kejadian Penyakit}

Pemberian PGPR berpengaruh nyata terhadap kejadian penyakit pada buah. Buah yang terserang penyakit pada perlakuan tanpa PGPR tampak lebih banyak dibandingkan

Tabel 4. Diameter batang (mm) saat berumur 2 MST pada interaksi berbagai taraf pemberian PGPR dan pemupukan $\mathrm{P}$

\begin{tabular}{lcc}
\hline \multicolumn{2}{c}{ Pemupukan P } & \multicolumn{2}{c}{ Pemberian PGPR } \\
\cline { 2 - 3 }$\left(\right.$ SP-36 ha $\left.{ }^{-1}\right)$ & Tanpa PGPR & PGPR \\
\hline $250 \mathrm{~kg}$ & $2.947 \mathrm{a}$ & $2.543 \mathrm{~b}$ \\
$187.5 \mathrm{~kg}$ & $2.867 \mathrm{a}$ & $3.023 \mathrm{a}$ \\
$125 \mathrm{~kg}$ & $2.890 \mathrm{a}$ & $3.087 \mathrm{a}$ \\
$62.5 \mathrm{~kg}$ & $2.943 \mathrm{a}$ & $2.530 \mathrm{~b}$ \\
\hline
\end{tabular}

Keterangan : angka yang diikuti oleh huruf yang sama pada kolom dan baris yang berbeda menunjukkan tidak berbeda nyata menurut hasil uji DMRT pada taraf 5\%

Tabel 5. Jumlah cabang pada berbagai taraf pemberian PGPR dan pemupukan $\mathrm{P}$

\begin{tabular}{lrrrrr}
\hline \multirow{2}{*}{ Perlakuan } & \multicolumn{4}{c}{ Umur tanaman } \\
\cline { 2 - 6 } & $2 \mathrm{mst}$ & $4 \mathrm{mst}$ & $6 \mathrm{mst}$ & $8 \mathrm{mst}$ & $10 \mathrm{mst}$ \\
\hline Pemberian PGPR & & & & \\
\hline Tanpa PGPR & 1.041 & 20.43 & 45.859 & 171.631 & $273.993 \mathrm{~b}$ \\
PGPR & 1.065 & 20.663 & 49.913 & 181.316 & $363.589 \mathrm{a}$ \\
\hline Pemupukan P (SP-36 ha-1) & & \\
\hline $250 \mathrm{~kg}$ & 1.130 & 21.242 & 51.090 & 185.245 & $338.342 \mathrm{a}$ \\
$187,5 \mathrm{~kg}$ & 1.023 & 20.918 & 48.558 & 178.318 & $315.668 \mathrm{~b}$ \\
$125 \mathrm{~kg}$ & 1.058 & 20.692 & 47.795 & $174.893319 .690 \mathrm{ab}$ \\
$62,5 \mathrm{~kg}$ & 1.000 & 19.335 & 44.100 & 167.437 & $301.463 \mathrm{~b}$ \\
\hline
\end{tabular}

Keterangan : angka yang diikuti oleh huruf yang sama pada kolom dan baris yang berbeda menunjukkan tidak berbeda nyata menurut hasil uji DMRT pada taraf 5\% 
buah dari tanaman yang diberi perlakuan PGPR (Tabel 8). Pemberian PGPR dan pemupukan $\mathrm{P}$ pada berbagai taraf tidak memberikan nyata terhadap kejadian penyakit selama satu musim, baik secara tunggal maupun interaksi kedua perlakuan.

\section{Viabilitas Benih}

PGPR berpengaruh sangat nyata terhadap Daya Berkecambah (DB), dan pengaruh yang nyata terhadap Indeks Vigor (IV) pada pengujian viabilitas benih awal. Tabel 9 menunjukkan bahwa pemberian PGPR secara langsung meningkatkan daya berkecambah hingga mencapai 90\% dan indeks vigor mencapai 30\%. Persentase nilai kecepatan tumbuh antar perlakuan penggunaan PGPR dan tanpa PGPR menunjukan hasil yang hampir sama yaitu sekitar 7.1\%. Pengujian mutu benih yang dihasilkan oleh tanaman yang diberi perlakukan PGPR menunjukkan tidak

Tabel 6. Jumlah cabang umur 10 MST pada interaksi berbagai taraf pemberian PGPR dan pemupukan $\mathrm{P}$

\begin{tabular}{lcc}
\hline \multirow{2}{*}{$\begin{array}{c}\text { Pemupukan P } \\
(\text { SP-36 ha-1) }\end{array}$} & \multicolumn{2}{c}{ Pemberian PGPR } \\
\cline { 2 - 3 } $250 \mathrm{~kg}$ & Tanpa PGPR & PGPR \\
$187.5 \mathrm{~kg}$ & $275.48 \mathrm{c}$ & $401.21 \mathrm{a}$ \\
$125 \mathrm{~kg}$ & $271.51 \mathrm{c}$ & $359.82 \mathrm{~b}$ \\
$62.5 \mathrm{~kg}$ & $281.13 \mathrm{c}$ & $358.82 \mathrm{~b}$ \\
\hline
\end{tabular}

Keterangan : angka yang diikuti oleh huruf yang sama pada kolom dan baris yang berbeda menunjukkan tidak berbeda nyata menurut hasil uji DMRT pada taraf 5\%

Tabel 7. Bobot buah per tanaman, bobot buah layak pasar per tanaman, dan jumlah buah per tanaman pada berbagai taraf pemberian PGPR dan pemupukan $\mathrm{P}$

\begin{tabular}{lccc}
\hline \multicolumn{1}{c}{ Perlakuan } & $\begin{array}{c}\text { Bobot buah } \\
\text { per tanaman } \\
(\mathrm{g})\end{array}$ & $\begin{array}{c}\text { Bobot buah } \\
\text { layak pasar } \\
(\mathrm{g})\end{array}$ & $\begin{array}{c}\text { Jumlah buah } \\
\text { per tanaman }\end{array}$ \\
\hline Pemberian PGPR & & & \\
\hline Tanpa PGPR & 135.78 & 112.88 & 15.92 \\
PGPR & 140.30 & 122.76 & 16.50 \\
\hline Pemupukan P (SP-36 ha-1) & & \\
\hline $250 \mathrm{~kg}$ & 130.31 & 109.48 & 14.67 \\
$187.5 \mathrm{~kg}$ & 144.49 & 120.24 & 16.00 \\
$125 \mathrm{~kg}$ & 132.22 & 118.35 & 17.17 \\
$62.5 \mathrm{~kg}$ & 145.14 & 123.23 & 17.00 \\
\hline
\end{tabular}

Keterangan : angka yang diikuti oleh huruf yang sama pada kolom dan baris yang berbeda menunjukkan tidak berbeda nyata menurut hasil uji DMRT pada taraf 5\% adanya pengaruh nyata. Pemupukan P dan perlakuan PGPR secara umum diketahui berpengaruh terhadap pertumbuhan produksi, kejadian penyakit dan mutu benih tanaman yang dihasilkan suatu tanaman budidaya. Namun studi pada tanaman cabai belum dilakukan.

Hasil pengamatan menunjukkan pemupukan $\mathrm{P}$ meningkatkan pertumbuhan, tapi tidak berpengaruh terhadap serangan penyakit antraknosa maupun produksi tanaman cabai. Penelitian Nam et al. (2006) menunjukkan kejadian penyakit antraknosa strawberry tidak dipengaruhi oleh dosis pemupukan P. Pengunaan PGPR hanya meningkatkan variabel pertumbuhan cabai yaitu jumlah cabang. Peran PGPR lebih pada menurunkan serangan penyakit antraknosa seperti yang dikemukakan oleh Sutariati (2006). Berkaitan dengan mutu benih PGPR berpengaruh terhadap mutu benih bila diaplikasi langsung namun tidak berpengaruh nyata terhadap mutu benih tanaman yang diberi PGPR .

Penggunaan PGPR menunjukkan interaksi dengan dosis pupuk $\mathrm{P}$ dalam meningkatkan pertumbuhan tanaman cabai baik pada tinggi tanaman, diameter batang maupun jumlah cabang. Dosis pupuk optimum adalah $125 \mathrm{~kg}$ SP $36 \mathrm{ha}^{-1}$. Dosis pupuk P tidak berpengaruh terhadap pertumbuhan. Hal ini berkaitan dengan peningkatan efisiensi pemupukan P karena PGPR, mampu menghasilkan asamasam organik yang meningkatkan efisiensi pemupukan $\mathrm{P}$ (Zabihi et al, 2011). Produksi cabai dalam penelitian ini tidak dipengaruhi oleh PGPR, pemupukan $\mathrm{P}$ maupun interaksinya, karena adanya faktor lain selain pertumbuhan dan serangan antraknosa yang cukup besar berperan yaitu serangan lalat buah.

Tabel 8. Kejadian penyakit pada buah pada berbagai taraf pemberian PGPR

Pemberian PGPR $\quad$ Kejadian penyakit buah (\%)

\begin{tabular}{ll}
\hline Tanpa PGPR & $20.861 \mathrm{a}$ \\
PGPR & $11.183 \mathrm{~b}$ \\
\hline
\end{tabular}

Keterangan: angka yang diikuti oleh huruf yang sama pada kolom yang sama menunjukkan tidak berbeda nyata menurut hasil uji DMRT pada taraf 5\%

Tabel 9. DB, IV, dan KCT benih cabai pada berbagai taraf pemberian PGPR

\begin{tabular}{lccccccc}
\hline & \multicolumn{3}{c}{ Awal } & \multicolumn{3}{c}{ Akhir } \\
\cline { 2 - 7 } Perlakuan & $\begin{array}{c}\text { DB } \\
(\%)\end{array}$ & $\begin{array}{c}\text { IV } \\
(\%)\end{array}$ & $\begin{array}{c}\text { KCT } \\
(\% / e t m a l)\end{array}$ & $\begin{array}{c}\text { DB } \\
(\%)\end{array}$ & $\begin{array}{c}\text { IV } \\
(\%)\end{array}$ & $\begin{array}{c}\text { KCT } \\
(\% / \text { etmal })\end{array}$ \\
\hline Tanpa & & & & & & \\
PGPR & $71.667 \mathrm{~b}$ & $12 \mathrm{~b}$ & 7.080 & 84.5 & $11.67 \mathrm{a}$ & 10.783 \\
PGPR & $92.000 \mathrm{a}$ & $30 \mathrm{a}$ & 7.167 & 86.0 & $10.67 \mathrm{~b}$ & 11.034 \\
\hline
\end{tabular}

Keterangan : $\mathrm{DB}=$ daya berkecambah, $\mathrm{IV}=$ indeks vigor, $\mathrm{KCT}$ = kecepatan tumbuh. Angka yang diikuti oleh huruf yang sama pada kolom dan baris yang berbeda menunjukkan tidak berbeda nyata menurut hasil uji DMRT pada taraf 5\% 


\section{KESIMPULAN}

Aplikasi pupuk $\mathrm{P}$ terhadap peubah pertumbuhan tanaman cabai tidak memberikan pengaruh terhadap penyakit antraknosa. PGPR mampu mengendalikan antraknosa pada kondisi lapang dan meningkatkan pertumbuhan serta daya hasil. Aplikasi PGPR meningkatkan daya tumbuh dan indeks vigor pada benih. PGPR dan dosis pupuk P menunjukan interaksi terhadap pertumbuhan dengan dosis optimal adalah $125 \mathrm{~kg}$ SP $36 \mathrm{ha}^{-1}$.

\section{DAFTAR PUSTAKA}

[BPS] Badan Pusat Statistik. 2005. Production of vegetables in Indonesia. http://www.bps.go.id [22 Juli 2007].

[Deptan] Departemen Pertanian. 2005. Produktivitas nasional. http://www.deptan.go.id [22 Juli 2007].

Duriat, A.S., A. Widjaya, W. Hadisuganda, T.A. Soetiarso, L. Prabaningrum. 1999. Teknologi Produksi Benih Cabai Merah. Balai Penelitian Tanaman Sayuran. Bandung.

Hasanudin. 2002. Peningkatan kesuburan tanah dan hasil kedelai akibat inokulasi mikrobia pelarut fosfat dan azotobacter pada ultisol. Jurnal Ilmu-Ilmu Pertanian 4(2):97-103.
Nam, M.H., S.K. Jeong, S. Lee, J.M. Choi, H.G. Kim. 2006. Effect of nitrogen, phosphorous, postasiium and calcium nutrition on strawberry antrachnose. Plant Pathology (55): 246-249 .

Sadjad, S., E. Muniarti, S. Ilyas. 1999. Parameter Pengujian Vigor Benih dari Komparatif ke Simulatif. Jakarta: Grasindo. 183 hal.

Semangun, H. 1996. Pengantar Ilmu Penyakit Tumbuhan. Gadjah mada University Press. Yogyakarta. 754 hal.

Sutariati, G.A.K. 2006. Perlakuan benih dengan biokontrol untuk pengendalian penyakit antraknosa, peningkatan hasil dan mutu benih cabai. Disertasi. Pascasarjana IPB. Institut Pertanian Bogor. Bogor. 163hal.

Zabihi, HR, G.R. Savaghebi, K. Khavazi, A. Ganja, M. Miransari. 2011. Pseudomonas bacteria and phosphorous fertilization, affecting wheat (Triticumaestivum L.) yield and P uptake under greenhouse and field conditions. Acta Physiologiae Plantarum. 33 (1):145-152 